\title{
APPLICATION OF GAHARU-C FORMULATION (ORGANIC AND INORGANIC) FERTILIZER ON AGARWOOD PLANT AT SPECIFIC LOCATION IN TABANAN REGENCY
}

\author{
I Made Mega* and A.A. Nyoman Supadma \\ Program Study of Agroecotechnology, Faculty of Agriculture, Udayana University, \\ Jl. PB. Sudirman Denpasar, Indonesia \\ *Coressponding author: mega_made@yahoo.com
}

\begin{abstract}
This study aim is to determine the effect of the application of Gaharu-C fertilizer formulation of sapwood formed on agarwood plants at three specific locations in Tabanan Regency. This research is a factorial experiment with basic CRD design (completely randomized design). The first factor is location specific consisting of 3 location namely: Pupuan Subdistrict $(\mathrm{Pu})$, Penebel Subdistrict (Pnl), and District of East Selemadeg $(\mathrm{Sl})$. The second factor was the treatment of the Gaharu-C formula fertilizer consisting of 2 ie: 0 (without fertilizer), and $\mathrm{C}$ (Gaharu-C fertilizer formulation: $100 \mathrm{~g}$ urea $+100 \mathrm{~g} \mathrm{SP}-36+100 \mathrm{~g} \mathrm{KCl})+(7.5 \mathrm{~kg}$ compost ) $+(75 \mathrm{~g}$ dolomite $)$ per tree $)$, each treatment replicated three times. Number of plants used as many as 18 trees. Parameters observed included increased stem diameter, sapwood color, weight of sapwood, resin content and soil chemical properties data. Data analysis used variance analysis and LCD test $(\alpha=0.05)$. The results showed that specific-location factors had significant effect on increasing stem diameter. However, had no significant effect on the color of sapwood, sapwood weight and resin level of sapwood. The fertilizer factor of Gaharu-C formula has no significant effect on all parameters observed. The highest increase of stem diameter was obtained at Pupuan location $(0.40 \mathrm{~cm})$, followed by East Selemadeg $(0.32 \mathrm{~cm})$, and the lowest Penebel $(0.15 \mathrm{~cm})$. The weight of sapwood and the highest resin content was obtained at the S1 C treatment of $5.34 \mathrm{~g}$ and $6.43 \%$. The best application of Gaharu-C fertilizer formulation is in East Selemadeg Subdistrict.
\end{abstract}

Keywords: Gaharu-C, agarwood plant, specific location

\section{INTRODUCTION}

Agarwood tree (Gyrinops versteegii) is one of a commodity categorized as nontimber forest product (NTFP) which has high economic value and could become an export commodity as well as good source of income for the community (Pasaribu et al., 2013). In addition, the government has declared agarwood to be a commodity of national nontimber forest products that needs to be developed on a wider scale (Santosa, 2009). Since 2000-2002 the volume of Indonesian agarwood exports is only reached 30 tons, with an export value of 600,000 US dollars. The high demands of agarwood sapwood abroad are due to the many benefits of agarwood, such as perfume, cosmetics, and medicines as well as for religious ritual purposes (Tarigan, 2004). However, Indonesia's agarwood production is relatively 
low and continues to decline with an average production of around 45 tons per year.

The decline of agarwood production is likely because of the relatively high intensity of natural agarwood harvesting, without any preservation efforts. In order to preserve the continuity of agarwood production and not rely on natural agarwood production. Effort is needed to cultivate agarwood plants to be able to produce good quality sapwood.

In the effort to increase the growth and establishment of the sapwood, applying a balanced fertilizer technology package that is fertilization by using organic fertilizers, natural fertilizers, and artificial (inorganic) fertilizers. Organic fertilizers can provide complete nutrients in low quantities, but also can improve the physical and biological properties of the soil. However, inorganic fertilizers will be able to provide more nutrients and are more readily available to plants compared to organic fertilizers, while natural fertilizers (dolomite) can provide more specific nutrients such as $\mathrm{Ca}$ and $\mathrm{Mg}$ nutrients which are essential for plants (Rosmarkam and Yuwono, 2002). In addition, providing a balanced fertilizer, (Mega et al., 2012) stating that to be able to accelerate and to increase the establishment of the sapwood, agarwood should be inoculated with mixed inoculants Fusarium sp. and Rhizopus sp.
The study to obtain the appropriate and balanced fertilizer formulations (organic + inorganic) to enhance the formation of agarwood sapwood on agarwood plants (Gyrinops versteegii) was conducted. The results of this study showed the treatment of formulation C (100 g urea $+100 \mathrm{~g} \mathrm{SP}-36+$ $100 \mathrm{~g} \mathrm{KCl})+(7.5 \mathrm{~kg}$ compost $)+(75 \mathrm{~g}$ dolomite) per tree, which produced stem circumference of $25.67 \mathrm{~mm}$, weight of sapwood is around 14.39 gram, and successive resin yields of 3.85\%. (Mega and Supadma, 2018). Furthermore, the formulation was named agarwood-C or Gaharu-C fertilizer. Given the cultivation of agarwood in Tabanan regency spread throughout the sub-district, as follows: Pupuan District, Penebel, West Selemadeg, Selemadeg, East Selemadeg, Kerambitan, and Marga District. The area has a variety of topography and slope topography), soil types and varies of climate (temperature and rainfall), it is necessary to apply Gaharu-C fertilizer formulation in several locations.

Based on the above problems, the research of the application of Gaharu-C fertilizer formulation was carried out in order to increase the establishment of sapwood in agarwood plants (Gyrinops versteegii) at specific locations in Tabanan regency. The result of this research is the fertilization technology package that consists of gaharu-C fertilizer formulation in several specific 
locations, will be useful to help the growth and to increase agarwood and sapwood production on inoculated plants. Based on the results of this study, it can be suggested to the government, especially the Forestry Department as the policy holder, to apply the results of this study in fostering farmers to improve the production of agarwood plant.

\section{MATERIALS AND METHODS}

This research is a field experiment on the agarwood plantations owned by farmers in Pupuan District, Penebel District, and East Selemadeg District at Tabanan Regency. This research started from June to November 2017, starting from preparation to reporting.

The materials/ingredients used in this research consists of mature compost (compost from Simantri product in Bali), agarwood tree with age >5 years old, Fusarium mushroom inoculant, plasticine, cotton, labeled paper, urea fertilizer, SP-36 and $\mathrm{KCl}$, and natural dolomite fertilizer. The tools needed for this research include $\mathrm{pH}$ stick, wood drill, hoe, sickle, stationery, plastic rope, and knives, flame-sensors, kjeldahl tools, spectrophotometers, and others.

This research is a factorial experiment with a basic design using a completely randomized design (CRD). The first factor is the specific location (L) which consists of 3 locations, namely: 1) Pu: Pupuan District, 2)
Pnl: sPenebel District, 3) Sl: East Selemadeg District. The second factor is the application of Gaharu-C (F) fertilizer which consists of 2 treatments: 1) 0: without fertilizer (control), 2) $\mathrm{C}:(100 \mathrm{~g}$ urea $+100 \mathrm{~g} \mathrm{SP}-36+100 \mathrm{~g}$ $\mathrm{KCl})+(7,5 \mathrm{~kg}$ compost $)+(75 \mathrm{~g}$ dolomite $)$ per tree.

Each treatment was replicated three times, so the total of the tree used are 18 agarwood plants. The parameters which are observed of 3 months after fertilization consists of growth parameter and sapwood establishment, as well as some soil chemical properties, namely: stem diameters $(\mathrm{cm})$, the weight of agarwood sapwood (g), resin content (\%) carried out by extracting sapwood with methanol $150 \mathrm{ml}$ for 3 hours. The resin yield is calculated by dividing the weight of the resin produced by the weight of the sap extracted by 100 times (Pasaribu et al., 2013). Soil chemical properties after 3 months of fertilization that consist of $\mathrm{pH}(\mathrm{pH}$ meter), organic-C (Walkley and Black), and total $\mathrm{N}$ content (Kjeldahl), P-available (Spectrophotometer), and K-available (Flame photometer) were analyzed at the Soil Laboratory Faculty of Agriculture, Udayana University. The data were statistically analyzed by ANOVA followed by the LSD test at $5 \%$ level. 


\section{RESULTS AND DISCUSSION}

The results of statistical analysis showed that the location treatment had a significant effect on increasing the diameter of the agarwood stem. While the effect was not significant on sapwood color, sapwood weight, and resin content on agarwood sapwood (Table 1 and Table 2). The color of the sap ranges from brown to blackish brown. The highest diameter agarwood plant stem after three months of treatment of Gaharu-C fertilizer formulation was obtained at the treatment location $\mathrm{Pu}(0.40 \mathrm{~cm})$ significantly different from the treatment of Pnl $(0.15 \mathrm{~cm})$ and $\mathrm{Sl}(0.32 \mathrm{~cm})$.

Table 1. Effect of location treatment and fertilization on sapwood color

\begin{tabular}{|c|c|c|}
\hline Treatment & \multicolumn{2}{|c|}{ Fertilization Aplication } \\
\hline Location & Control (0) & Fertilizer $(\mathrm{C})$ \\
\hline \multirow[t]{2}{*}{$\mathrm{Pu}$} & & \\
\hline & Brown & Brown \\
\hline \multirow[t]{2}{*}{ Pnl } & & \\
\hline & Brown & Blackish-Brown \\
\hline \multirow[t]{2}{*}{$\mathrm{Sl}$} & & \\
\hline & Brown & Blackish-Brown \\
\hline
\end{tabular}


Table 2. Effect of location on increasing stem diameter, sapwood weight and resin Content

\begin{tabular}{cccc}
\hline Treatment & Stem diameter $(\mathrm{cm})$ & Sapwood weight $(\mathrm{g})$ & Resin content $(\%)$ \\
\hline $\mathrm{Pu}$ & $0.40 \mathrm{~b}$ & $4.20 \mathrm{a}$ & $4.82 \mathrm{a}$ \\
$\mathrm{Pnl}$ & $0.15 \mathrm{a}$ & $5.14 \mathrm{a}$ & $4.55 \mathrm{a}$ \\
$\mathrm{S} 1$ & $0.32 \mathrm{a}$ & $5.31 \mathrm{a}$ & $5.88 \mathrm{a}$ \\
\hline LSD 5\% & 0.18 & - & - \\
\hline
\end{tabular}

Note : The value on the same colums followed by the same letter indicated statistically insignificant according to LSD level at $5 \%$.

Treatment of Gaharu-C formula sapwood weight, and sapwood resin content application did not significantly affect the (Table 3).

increase of stem diameter, sapwood color,

Table 3. Effect of fertilizer application on increasing stem diameter, sapwood weight and resin content

\begin{tabular}{cccc}
\hline Treatment & Stem diameter $(\mathrm{cm})$ & Sapwood weight $(\mathrm{g})$ & Resin content $(\%)$ \\
\hline 0 & $0.23 \mathrm{a}$ & $5.10 \mathrm{a}$ & $4.77 \mathrm{a}$ \\
$\mathrm{C}$ & $0.35 \mathrm{a}$ & $4.67 \mathrm{a}$ & $5.40 \mathrm{a}$ \\
\hline
\end{tabular}

Note : The value on the same colums followed by the same letter indicated statistically insignificant according to LSD level at $5 \%$.

The location treatment and tendency to increase the weight of sap and application of fertilization had no significant resin content compared to the control in each effect on the increase of the stem diameter location. The highest sap weight and resin and resin content. Although the influence of content were found in Sl C treatment, the treatment is not real, but there is a respectively: $5.34 \mathrm{~g}$ and $6.43 \%$ (Table 4).

Table 4. Effect of location and application of fertilization to increase stem diameter, sapwood weight and resin content.

\begin{tabular}{cccc}
\hline Treatment & Stem diameter $(\mathrm{cm})$ & Sapwood weight $(\mathrm{g})$ & Resin content $(\%)$ \\
\hline Pu 0 & $0.38 \mathrm{a}$ & $4.91 \mathrm{a}$ & $4.78 \mathrm{a}$ \\
$\mathrm{Pu} \mathrm{C}$ & $0.41 \mathrm{a}$ & $3.49 \mathrm{a}$ & $4.85 \mathrm{a}$ \\
Pnl 0 & $0.15 \mathrm{a}$ & $5.11 \mathrm{a}$ & $4.20 \mathrm{a}$ \\
Pnl C & $0.15 \mathrm{a}$ & $5.17 \mathrm{a}$ & $4.91 \mathrm{a}$ \\
S1 0 & $0.15 \mathrm{a}$ & $5.28 \mathrm{a}$ & $5.33 \mathrm{a}$ \\
Sl C & $0.50 \mathrm{a}$ & $5.34 \mathrm{a}$ & $6.43 \mathrm{a}$ \\
\hline
\end{tabular}

Note : The value on the same colums followed by the same letter indicated statistically insignificant according to LSD level at $5 \%$. 
When the parameters of plant growth and sapwood formation and resin are associated with nutrient levels after three months of fertilization formulation application, it could be seen that each location is increased compared to the control
(Table 5). The treatment of Penebel location gave the highest total C-organic nutrient and $\mathrm{N}$ levels, respectively: $5.31 \%, 0.39 \%$. Likewise, when viewed the levels of Corganic soil have increased in all treatments compared to the initial soil C-organic.

Table 5. Treatment effect that changing some soil chemical properties after three months administration to agarwood plantations

\begin{tabular}{lccccc}
\hline \multicolumn{1}{c}{ Treatment } & $\mathrm{pH}$ & C-organic & N-total & P-available & K-available \\
\hline Pu 0 & 6.2 & 4.61 & 0.35 & 10.21 & 206.10 \\
Pu C & 6.2 & 4.34 & 0.33 & 32.91 & 250.71 \\
Pnl 0 & 6.3 & 2.23 & 0.14 & 267.25 & 210.42 \\
Pnl C & 6.2 & 5.31 & 0.39 & 314.81 & 231.56 \\
S1 0 & 6.3 & 2.22 & 0.30 & 145.70 & 201.02 \\
S1 C & 6.3 & 3.45 & 0.22 & 403.24 & 243.17 \\
Pu pretreatment & 6.2 & 2.86 & 0.19 & 10.30 & 208.26 \\
Pnl pretreatment & 6.2 & 4.49 & 0.20 & 708.80 & 212.34 \\
Sl pretreatment & 6.3 & 2.65 & 0.14 & 151.04 & 205.11 \\
\hline
\end{tabular}

Based on the observations and the nutrient conditions in the soil at the statistical tests, it showed that the effect of Pupuan location treatment which contains treatment location was significantly different high c-organic, moderate total $\mathrm{N}$, very high from the parameters of stem diameter of the $\mathrm{P}$-available, and very high $\mathrm{K}$-available, and a plant, but did not significantly affect the slightly acidic $\mathrm{pH}$, so it is very helpful to cell color of sapwood, sapwood weight, and resin content in agarwood sapwood. The highest diameter increase was obtained at Pupuan (Pu) location, which was $0.40 \mathrm{~cm}$, followed by Selemadeg $(\mathrm{Sl})$ of $0.32 \mathrm{~cm}$ and the lowest is Penebel (Pnl) of $0.15 \mathrm{~cm}$. This is due to the fastest growth of plants in the Pupuan area, presumably due to the highest c-organic content and $\mathrm{N}$-total levels in the soil compared to other treatments, namely $4.43 \%$ (high) and $0.34 \%$ (moderate). The growth of the agarwood plant is strongly supported by growth in plant stems (Rosmarkam et al., 2003). The soil chemical properties factors are very influential on plant growth, especially nutrient levels of $\mathrm{N}, \mathrm{P}$, and $\mathrm{K}$ (Erfandi and Kasno, 2000), thus causing the largest increase in stem diameter.

The application of Gaharu-C fertilizer formulation application had no significant effect on all parameters observed, at each location. Although the effect is not real, but there is a tendency of an increase in sapwood weight and resin content in all study 
locations. Sapwood weight increased by $11.74 \%$ at Penebel location and $11.36 \%$ at East Selemadeg location in fertilizing treatment compared to control (without fertilizer). While there was an increase in resin levels due to the effect of gaharu-C fertilizer application on each location, namely: Pupuan (14.64\%), Penebel (16.90\%), and East Selemadeg (2.06\%). This is supported by the results of previous studies of the most gaharu sapwood formation achieved in fertilization treatment with $\mathrm{C}$ formulation : (100 g urea $+100 \mathrm{~g} \mathrm{SP}-36+$ $100 \mathrm{~g} \mathrm{KCl})+(7.5 \mathrm{~kg}$ compost $)+(75 \mathrm{~g}$ dolomite) per tree that produces gaharu sapwood by 14.39 g (Mega and Supadma, 2016), agarwood sap contains furan compounds and ester groups which can be measured by the formation of resin produced by agarwood sapwood extraction (Pasaribu et al., 2012).

The sapwood forming on agarwood is highly determined by the occurrence of the infection of agarwood stems by Fusarium solani and Rhizopus sp. that given through inoculation at several points on the stem of the agarwood plant. According to Mega et al. (2012) that the administration of a combination of Fusarium solani and Rhizopus sp. can increase the formation of the best agarwood sapwood. In this study, the formation of agarwood sapwood (sap weight) and the highest resin content was achieved in the treatment of east Selemadeg location and the treatment application of Gaharu-C fertilizer was $5.34 \mathrm{~g}$ and $6.43 \%$ respectively. This was allegedly caused by physical environmental conditions in the eastern Selemadeg site which consisted of climate (rainfall of $2263 \mathrm{~mm} / \mathrm{year}$ and dry month 3.21 months, and the annual average temperature of $25.9^{\circ} \mathrm{C}$ ), and nutrient content in brown Latosol yellowish soil provides the best conditions for growth and formation of sapwood. According to van't Hoff (in Hardjowigeno, 2003) saying that every $10^{\circ} \mathrm{C}$ increase in temperature the speed of the chemical reaction will increase two to three times.

\section{CONCLUSIONS}

Based on the results of this study, some conclusions can location-specific factors have a significant effect on increasing stem diameter but have no significant effect on sapwood color, sapwood weight and resin content in agarwood sapwood The factor of Gaharu-C fertilizer formula has no significant effect on sapwood color, sapwood weight and resin content in agarwood sapwood The highest increase in stem diameter was obtained at Pupuan location $(0.40 \mathrm{~cm})$, followed by east Selemadeg $(0.32$ $\mathrm{cm})$, and the lowest Penebel $(0.15 \mathrm{~cm})$. The highest sap weight and resin content were obtained in SIC treatment (Gaharu-C 
fertilizer formulation in east Selemadeg) of $5.34 \mathrm{~g}$ and $6.43 \%$. The best location for the application of the Gaharu-C fertilizer formulation is in the eastern Selemadeg district.

\section{ACKNOWLEDGEMENT}

Thank you to the Rector of Udayana University for financial assistance and permission granted, so that this research can be smoothly.

\section{REFERENCES}

Erfandi, D.,A. Kasno, (2000). Efektivitas Penggunaan Pupuk anorganik dan organik untukmeningkatkan Produktivitas Tanah pada lahan kering masam. Prosiding HITI. VII. Bandung.

Hardjowigeno, S. (2003). Klasifikasi Tanah dan Pedogenesis. Penerbit Akademika Pressindo. Jakarta.

Mega, I. M., Suanda, D. W., Kasniari, D. N., Suena, W., \& Parwata, M. O. (2012). Formulasi Inokulan Jamur Pembentuk Gubal Gaharu pada Tanaman Ketimunan (Gyrinops versteegii). J. Agrotrop. Vol. 2. No.2. hal. 139-144.

Mega, I. M., \& Supadma, A. A. N. (2018). Study Of Fertilizer (Organic + Inorganic) Formulation to Improve Gubal Agarwood Formation in Ketimunan Tree (Gyrinops Versteegii). International Journal of Bioscience And Biotechnology, Vol. V No. 2 , April 2018 . p. 136-142

Pasaribu, G., Waluyo, T. K., \& Pari, G. (2013). Analisis Komponen Kimia Beberapa Kualitas Gaharu dengan Kromatografi Gas Spektrometri Massa. J. Penelitian Hasil Hutan, Vol. 31, No.3. hal. 181-185.
Rosmarkam, A., and Yuwono, N. W. (2002). Ilmu Kesuburan Tanah. Penerbit Kanisius. Yogyakarta.

Santosa, H. (2009). Konservasi dan Pemanfaatan Gaharu. Disampaikan dalam Seminar Nasional I Gaharu. Bogor.

Susila, D., and Mega, I. M. (2012). Aplikasi Pemupukan Berimbang untuk Peningkatan Laju Pertumbuhan Tanaman Gaharu (Gyrinops verstegii) di Kabupaten Tabanan. J.Agrotrop Vol. 2. No. 1. Hal.10-16.

Tarigan, K. (2004). Profil Pengusahaan (Budidaya) Gaharu. Departemen Kehutanan. Pusat Bina Penyuluhan Kehutanan. Jakarta. 